TURIZAM

Volume 18 , Issue 2

84-94 (2014)

\title{
Assessment of the Lodging Industry Profitability Performance: Invest in Independent or Chain Ownership?
}

Soultana Tania Kapiki*, Lei Mou**, Jing Fu**

Received: December 2013 | Accepted: March 2014

\section{Abstract}

The purpose of this article is to evaluate the economic results of the independent hotels in comparison with the chain hotels as well as to propose suggestions for the viability of the lodging industry.

The survey took place in Greece concerning the period 2008-2011 and it was conducted via on-line questionnaires among 165 hotel units. The average means of efficiency and profitability indicators of the sampled hotels are benchmarked and the data of 2009 are utilized to further compare their ratios by using ratio analysis. Furthermore, ANOVA test is used to conduct mean difference analysis in order to identify the differences among the means along with their associated variables between independent and chain hotels.

The main findings of the survey show that, generally, the independent hotels tend to be more profitable than chain hotels. The sector's good practices that have been identified through this study are highlighted as suggestions for the viability of the lodging industry both in Greece and worldwide.

Based on the findings of the survey, investors and hotel operators may have a clearer picture of whether it is preferable to invest their funds in the development of an independent hotel or they should turn to chain ownership.

Key words: Profitability performance, lodging industry, independent hotels, chain ownership, good practices

\section{Introduction}

Economic viability (sustainability) in hospitality involves using the assets of the property optimally and efficiently so as to allow it to continue functioning profitably over the longer term.

* Alexander Technological Educational Institute of Thessaloniki, P.O. Box 141, GR-57400 Thessaloniki, Greece, e-mail: tkapiki@tour.teithe.gr

** International e-Tourism Research Centre, Chengdu University, P. R. China No. 1 Shi Lin Upper City, Chengdu City, Sichuan Province, China, e-mail: cdu.mulei@gmail.com; fujingkm@gmail.com 
The viability of individual tourism enterprises depends on the ability to identify markets that will continue to deliver business in the long term; to understand what potential consumers are looking for; and to adapt to trends and changes in source market conditions, travel patterns and tastes. This requires effective and on-going market assessment to guide development in the hospitality properties (UNEP, 2005).

Few studies concerning the independent and chain hotels exist in the contemporary literature and thus the authors decided to conduct a survey in hotels of both types located in Greece so as to identify answers to the research problem.

The purpose of this study is to evaluate the economic results, in particular the profitability performance of the Greek independent hotels in comparison with the chain hotels as well as report good practices for the financial viability of the lodging industry.

In order to achieve the study purpose, the following procedures take place:

I. The Greek hotel supply as well as the total market size in value (turnover) of the Greek hotel enterprises is presented for the years 2008 - 2OII (Tables I and 2).

2. The authors quote the branded hotels operating in Greece in 2009 (Table 3), and, separately for the independent and chain hotels the sample's key data, such as the number of hotels, their classification, the total bed capacity and number of employees, the location and the total market share in terms of the overall amount of beds (Table 4).

3. Benchmarking as well as empirical average mean analysis are performed and the average mean for several key indicators of the sampled hotels for the period 20082OII is shown in the Table 5 .

4. The data of 2009 are utilized to further compare the ratios of the sampled hotels whose profit performances exceed the average mean by using ratio analysis. The results are illustrated in the Figures I-4 and summarized in Table 6.

5. ANOVA test is applied via SPSS package to conduct a Mean Difference Analysis presented in Table 7 .

6. Finally, good practices that have been identified through this study are highlighted as suggestions for the viability of the lodging industry both in Greece and worldwide.

\section{Literature Review}

Hotel properties can be grouped by ownership and affiliation into two basic equity structures: independent hotels and chain hotels. An independent hotel has no affiliation with other properties. Chain hotel ownership may take a number of forms, including management contracts, franchises and referral groups (Kasavana, Brooks, 2005).

When new hotels are developed and planned feasibility studies are conducted usually by independent consultants. A feasibility study can help investors decide whether the hotel project they are considering is economically viable. Among other elements the study includes competition analysis and financial estimates (Angelo, Vladimir, 2007).

Furthermore, prospective owners can use academic surveys, such as the one included in this paper in order to determine their ownership and affiliation.

The decision to be a franchise or chain affiliated hotel is one of the most critical decisions in a hotel investment. For many hotels the costs associated with purchasing and maintaining a franchise (6-8\% or more of revenue) represents the 2nd largest (after labour) expense category. While for many hotels affiliation can represent the difference between financial viability or failure, affiliation does not ensure successful financial performance. And in fact, 
certain types of hotels, depending upon their market positioning and segmentation, perform much better as independents (Raleigh, 1999).

The economic viability is part of the sustainable development strategy of many hotels. The objective is to create superior value to their shareholders and guests and the strategy is based on the concept of the "triple bottom line," which combines economic viability (profit) with social responsibility and environmental protection. A company must use sustainable development principles to grow revenues and save on costs thus remaining profitable to be sustainable (Houdre, 2008).

Hotels' reason to go sustainable is not limited to the pursuit of an environmental friendly approach. These environmentally friendly actions in hotels are usually related to economic benefits, competitiveness, brand image and meeting customers' expectations (Rahman, et al., 2OI2).

Whatever the origin is, the hospitality industry pays more attention to be sustainable because of the multiple benefits discovered. But the main motivation to be sustainable seems to be minimizing cost for economic benefits (Ozdogan, et al., 2OI3).

The pattern of concentration in the European hotel industry reflects the structure of the economies. Experience and market service economies (e.g. the UK and France) have the highest hotel concentration (chain room percentage of the country's total room capacity), while industrial economies such as Greece and Portugal have the lowest structural scores in the EU (Slattery, 2004).

The hospitality sector is the pillar of the Greek tourism industry but nonetheless, the large (over I.OOO beds) hotel groups and the international hotel chains operating in Greece in 2 OII control only 228 hotels and II6.4OO beds (ICAP, 2OI2).

Aimed at understanding the structure of the Greek hotel industry we quote below some key figures and indicators for the Greek hospitality sector (Tables I-3).

The Greek hotel supply in the years 2008 - 2OII was as follows (Table I).

Table 1. Hotel supply in Greece (2008-2011)

\begin{tabular}{|c|c|c|c|c|}
\hline Hotel Capacity / Indicator & 2008 & 2009 & 2010 & 2011 \\
\hline Hotels & 9.385 & 9.559 & 9.732 & 9.648 \\
\hline Rooms & 375.100 & 383.000 & 397.700 & 397.322 \\
\hline Beds & 715.857 & 732.279 & 763.407 & 763.668 \\
\hline Distribution of beds per class & $\begin{array}{r}5 * 78.464 \\
4 * 183.900 \\
3 * 169.941 \\
2 * 227.146 \\
1 * 56.406\end{array}$ & $\begin{array}{r}5 * 91.770 \\
4 * 187.494 \\
3 * 171.202 \\
2 * 226.707 \\
1 * 55.106\end{array}$ & $\begin{array}{r}5 * 102.428 \\
4 * 196.862 \\
3 * 177.923 \\
2 * 230.358 \\
1 * 55.835\end{array}$ & $\begin{array}{r}5 * 108.552 \\
4 * 193.381 \\
3 * 180.365 \\
2 * 226.539 \\
1 * 54.831\end{array}$ \\
\hline International arrivals per bed & 22,3 & 20,4 & 19,7 & 21,47 \\
\hline \multirow[t]{2}{*}{ Average hotel size in rooms } & 41 & 40 & & \\
\hline & 41 & 41,18 & & \\
\hline Average occupancy & $56,7 \%$ & $51,1 \%$ & $48,1 \%$ & $\mathrm{~N} / \mathrm{A}$ \\
\hline Revenue per available room (RevPAR) & $\mathrm{N} / \mathrm{A}$ & $15.328 €$ & $13.274 €$ & $14.491,2 €$ \\
\hline
\end{tabular}

Sources: SETE, Greek Chamber of Hotels, ICAP \& ITEP (2008 - 2012)

The market size (in value) of the upper class hotel enterprises is equal to the total sum of turnovers (sales) of all the Greek 5, 4 and 3-star hotels. The total market value of the Greek hospitality industry for the years 2008-2OII is presented in the Table 2. 
Table 2. Total market size in value (turnover) of the Greek hotel enterprises 2008-2011

\begin{tabular}{|r|r|r|}
\hline Year & $\begin{array}{c}\text { Market size (in } € \text { 000) } \\
\left(5^{*}-3^{*} \text { hotels) }\right.\end{array}$ & Change (\%) \\
\hline 2008 & 3.430 .000 & 5.2 \\
\hline 2009 & 2.980 .000 & -13.1 \\
\hline 2010 & 2.850 .000 & -4.4 \\
\hline 2011 & 3.100 .000 & 8.8 \\
\hline
\end{tabular}

Source: ICAP, Hotel Enterprises (2008-2012)

The market size (in value) of the $5^{*}-3^{*}$ Greek hotels has increased by $8,8 \%$ in 20 II in relation to 2OIO. The revenues of the 4-star hotels represent the largest share (about 46\%) of the Greek hospitality sector total value.

According to the latest Greek Hotel Branding Report, the branded hotels in Greece account only for $4 \%$ of the total number and $19 \%$ of the total availability of rooms, while in other EU countries this figure lies between 25 and 4O\% (http://www.msolutions.gr/projects/tourism/).

The Table 3 below shows the branded hotels operating in Greece in 2009.

Table 3. Branded hotels operating in Greece (2009)

\begin{tabular}{|l|r|r|r|r|r|}
\hline & No. of hotels & $\begin{array}{c}\text { Share of the coun- } \\
\text { try's hotels }\end{array}$ & $\begin{array}{c}\text { Total room ca- } \\
\text { pacity }\end{array}$ & $\begin{array}{c}\text { Share of the coun- } \\
\text { try's total room } \\
\text { capacity }\end{array}$ & $\begin{array}{c}\text { Average no. of } \\
\text { rooms per hotel }\end{array}$ \\
\hline $\begin{array}{l}\text { International Hotel } \\
\text { Brands }\end{array}$ & 104 & $1.1 \%$ & 21.667 & $5.4 \%$ & 208 \\
\hline $\begin{array}{l}\text { National Hotel } \\
\text { Brands }\end{array}$ & 155 & $1.6 \%$ & 31.639 & $5.8 \%$ & 204 \\
\hline Local Hotel Brands & 167 & $1.7 \%$ & 23.267 & $1.7 \%$ & 139 \\
\hline $\begin{array}{l}\text { Cypriot Hotel } \\
\text { Brands }\end{array}$ & 26 & $0.3 \%$ & 6.723 & $19 \%$ & 259 \\
\hline $\begin{array}{l}\text { All Branded Hotels } \\
\text { of Greece }\end{array}$ & 431 & $4 \%$ & 77.464 & 180 \\
\hline
\end{tabular}

Source: Koutoulas Hotel Database

\section{Methods and data}

In order to gather the required information, as well as to financially analyse the hotel companies and to identify the industry's best practices towards viability, the authors applied a methodological approach that includes the following steps:

- The lodging enterprises operating in Greece are grouped into two major segments: individual properties and chain hotels.

- An on-line questionnaire was developed and sent to 200 independent hotels and to the headquarters of 250 hotel chains (the latter publish consolidated balance sheets), aiming to collect key financial data for the period 2008-2OII as well as identify those practices having contributed to their viability. The hotel categories vary from 2-5 stars (although the responses from 2-star hotels are quite few) and the vast majority are city and resort hotels. 
- Benchmarking is conducted in the average mean between the independent and chain hotels during the period 2008-20IO, aiming to identify the tendency of the efficiency and profitability performances between independent and chain hotels.

- The authors focus on the data presented in 2009, and conduct a ratio analysis on the four indicators of profitability performance between the two types of the sampled hotels, whose profitability exceeds the average mean.

- Then an examination of whether the means of the profit indicators are significantly different for the two types of hotels is implemented by using ANOVA analysis. The data are processed and presented via SPSS I7.O.

The questions included in the questionnaire can be classified into three basic groups:

a) Those concerning the hotel key data, such as: number of hotels (included in the chain); classification, bed capacity; number of employees; location;

b) Questions asking for the property's economic performance in the last four years; and

c) Questions identifying good practices for the viability of the hospitality sector.

The technique used for selecting the 450 recipients of the questionnaire was the cluster sampling (independent/chain hotels) and then a simple random sample of these two groups was selected.

The questionnaire was sent in January 2013 and by May 20I3, 35 completed questionnaires from individual hotels and 42 from chain hotels were received. From the 42 answered questionnaires, seven were not complete and were excluded from the sample; therefore, the final number of the chain hotels is 35 . The response rate to the questionnaire was $17 \%$ and the sample's size (bed capacity equal to 76.777 that accounts for the I0.85\% of Greece's total $2^{*}-5^{*}$ capacity) is considered representative.

Whenever necessary, the data collected through the questionnaires were compared against published balance sheets and performance data and in case of variations the hotel managers were contacted again for further clarifications and additional information.

For the economic assessment of the sampled hotel properties, the authors use the variables efficiency and profitability. More specifically, for the purposes of this study, the efficiency of hotel enterprises is assessed by using the indexes Return on Equity and Return on Capital Employed. For the assessment of profitability the indexes of Gross Profit, Operating Profit, Net Profit and EBITDA margin are used (ICAP, 2OI2). Therefore, the hoteliers were invited to provide the above data for the period 2OO8-2OII.

EBITDA (earnings before interest, taxes, depreciation and amortization) can be used to analyse the profitability between companies and industries because it eliminates the effects of financing and accounting decisions (Ransley, 2004).

Following the collection of the answered questionnaires, elaboration of the answers and calculation of various financial indicators took place.

The sample's key data are presented in the Table 4.

For the economic assessment of the sampled hotels the authors benchmark and set out in the Table 5 below the indicators: Efficiency (Return on Equity \& Return on Capital Employed) and Profitability (Gross Profit Margin, Operating Profit Margin, Net Profit Margin \& EBITDA Margin). The average mean is compared between the two types of the hotels during the period of the four years (2008-2OII), and the results of the analysis are presented in two separate columns for each year, one for independent hotels (INDEP.) and one for chain hotels (CHAIN). In this way, the comparison for each index and year is more distinct. 
Table 4. Sample key data

\begin{tabular}{|c|c|c|c|c|c|}
\hline \multicolumn{3}{|c|}{ Independent Hotels (35 hotels) } & \multicolumn{3}{|c|}{ Chain Hotels ( 35 chains: 130 hotels) } \\
\hline Number of Hotels & Classification & Total Bed Capacity & Number of Hotels & Classification & Total Bed Capacity \\
\hline 19 & $5^{*}$ & \multirow{2}{*}{19.623} & 40 & $5^{*}$ & \multirow{4}{*}{57.154} \\
\hline 16 & $4^{*}$ & & 61 & $4^{*}$ & \\
\hline \multirow{3}{*}{\multicolumn{3}{|c|}{ Total Number of Employees: 4.837}} & 25 & $3^{*}$ & \\
\hline & & & 4 & $2^{*}$ & \\
\hline & & & \multicolumn{3}{|c|}{ Total Number of Employees: 13.052} \\
\hline \multicolumn{3}{|l|}{$\begin{array}{l}\text { Location: } \\
\text { City hotels (7) } \\
\text { Resort hotels (28) }\end{array}$} & \multicolumn{3}{|l|}{$\begin{array}{l}\text { Location: } \\
\text { City hotels (21) } \\
\text { Resort hotels (108) } \\
\text { Airport hotel (1) }\end{array}$} \\
\hline \multicolumn{3}{|c|}{$\begin{array}{l}\text { Total market share in terms of the overall amount of beds (Hotel } \\
\text { Categories } 5 * \& 4 *): 6,55 \%\end{array}$} & \multicolumn{3}{|c|}{$\begin{array}{l}\text { Total market share in terms of the overall amount of beds (Hotel } \\
\left.\text { Categories } 5^{*}, 4^{*}, 3^{*} \& 2^{*}\right): 8 \%\end{array}$} \\
\hline
\end{tabular}

Source: authors' own elaboration

Table 5. Benchmarking in average mean of the sampled hotels' key indicators (2008-2011)

\begin{tabular}{|l|r|r|r|r|r|r|r|r|}
\hline Index & \multicolumn{2}{|c|}{2008} & \multicolumn{2}{c|}{2009} & \multicolumn{2}{c|}{2010} & \multicolumn{2}{c|}{2011} \\
\hline$(\%)$ & INDEP. & \multicolumn{1}{|c|}{ CHAIN } & INDEP. & CHAIN & INDEP. & CHAIN & INDEP. & CHAIN \\
\hline Return on Equity & $-2,50$ & $-3,41$ & $-5,81$ & $-29,47$ & $-11,02$ & $-12,47$ & $-12,68$ & $-2,09$ \\
\hline Return on Capital Employed & $-1,48$ & 0,45 & $-0,205$ & $-1,62$ & $-2,618$ & $-1,80$ & $-0,835$ & $-0,74$ \\
\hline Gross Profit Margin & 17,37 & 15,84 & 15,66 & 14,93 & 14,19 & 9,52 & 18,77 & 15,27 \\
\hline Operating Profit Margin & $-1,48$ & $-7,83$ & $-6,20$ & $-11,19$ & $-9,94$ & $-12,59$ & $-2,77$ & $-7,91$ \\
\hline Net Profit Margin & $-4,96$ & $-5,48$ & $-6,92$ & $-11,76$ & $-11,43$ & $-12,49$ & $-3,68$ & $-9,23$ \\
\hline EBITDA Margin & 22,69 & 18,70 & 21,26 & 17,76 & 19,71 & 15,02 & 25,40 & 20,02 \\
\hline
\end{tabular}

Source: authors' own elaboration

The benchmarking analysis in the average mean of the sampled hotels' key indicators (Table 5) shows that, in general, during the period 2008-2OII the Greek independent hotels tend to be more profitable than the chain hotels.

The authors have to acknowledge that the components of the two types of sampled hotels are different. The type of the sampled independent hotels covers only 4-5 star hotels, while the type of chain hotels ranges from 2-5 stars. Furthermore, some data were not available throughout the four years. Therefore, the average mean analysis may not completely and accurately reflect the economic performances of the two groups. Thus, ratio analysis is adopted to benchmark the ratios of the sampled hotels whose profitability performances exceed the average mean. The four indicators of profitability in the year 2009 are selected, when the data are the most complete.

All the data of profitability indicators in the year 2009 are placed together (both independent hotels and chain hotels), and the average means of each indicator are obtained. Then the ratios of the sampled hotels whose profit margins exceed the average mean are calculated in order to understand which type of the sampled hotels is more profitable. The results are shown in the Figures I-4 and summarized in the Table 6.

From the Figures I-4 and the Table 6 below, it is shown that in 2009, the independent hotels gradually become more profitable than the chain hotels, but this superiority is not remarkable. 


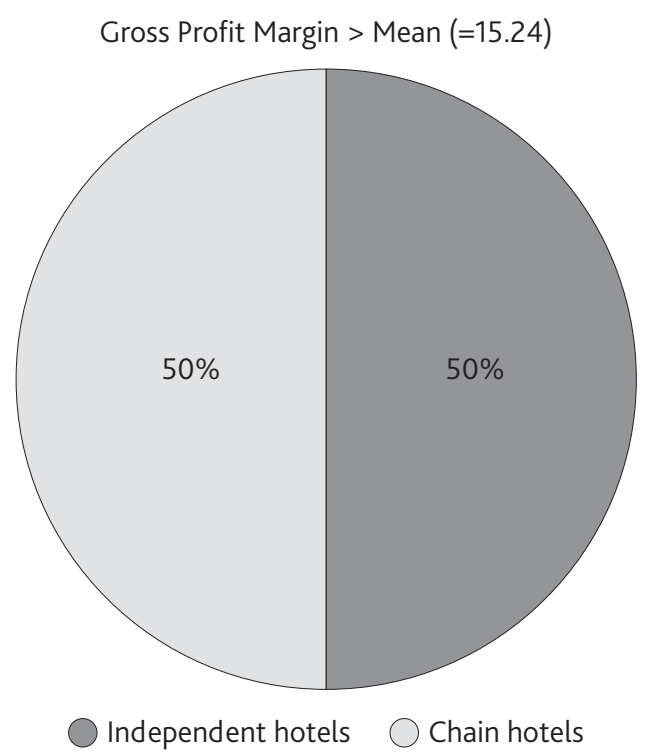

Figure 1. The ratio between independent hotels and chain hotels assessed by the Gross Profit Margin (2009)

Source: author's own elaboration

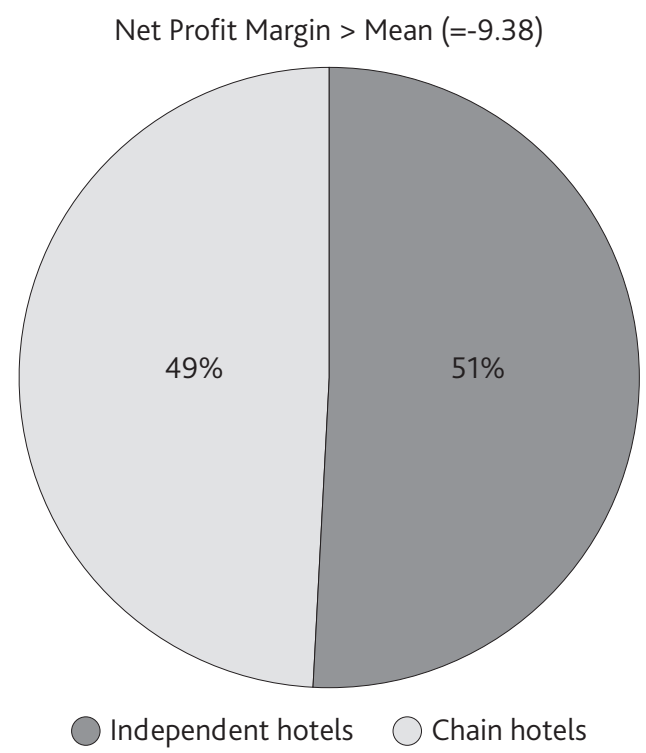

Figure 3. The ratio between independent hotels and chain hotels assessed by the Net Profit Margin (2009)

Source: authors' own elaboration
Operating Profit Margin > Mean $(=-8.74)$

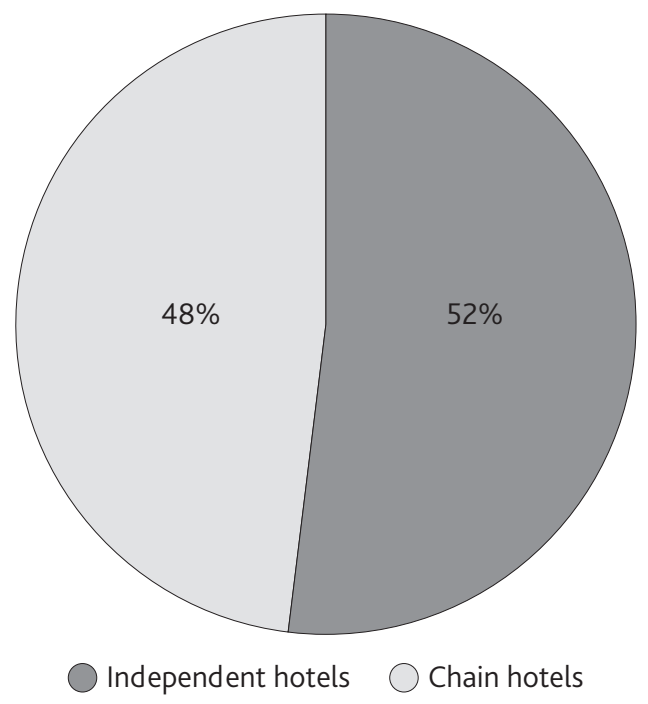

Figure 2. The ratio between independent hotels and chain hotels assessed by the Operating Profit Margin (2009)

Source: authors' own elaboration

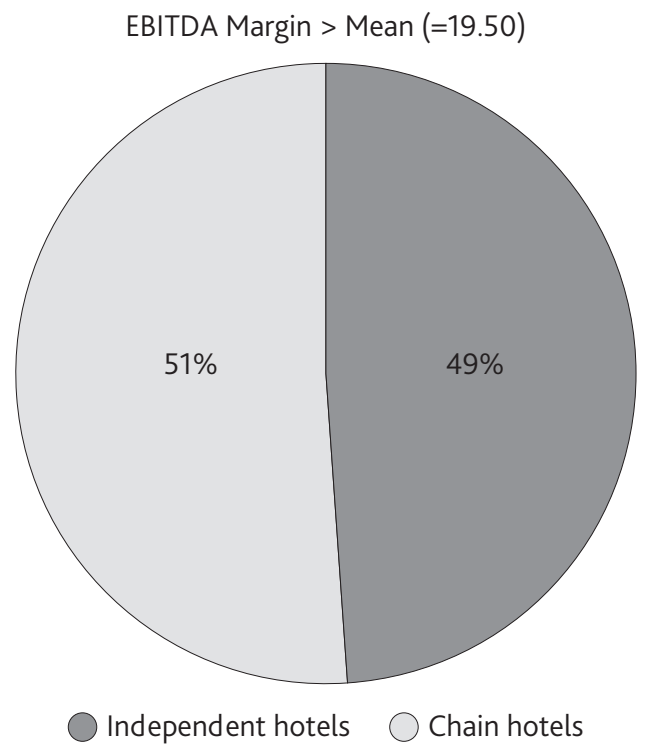

Figure 4. The ratio between independent hotels and chain hotels assessed by the EBITDA Margin (2009)

Source: authors' own elaboration 
Table 6. Benchmarking in profitability indicators between the sampled hotels whose profit performances exceed the average mean (2009)

\begin{tabular}{|l|r|r|r|}
\hline Profitability Indicators & \multicolumn{1}{|c|}{ Independent Hotels } & \multicolumn{1}{|c|}{ Chain Hotels } \\
\hline Gross Profit Margin & 15.24 & 20 & 20 \\
\hline Operating Profit Margin & -8.74 & 52 & 48 \\
\hline Net Profit Margin & -9.38 & 24 & 23 \\
\hline EBITDA Margin) & 19.50 & 19 & 20 \\
\hline
\end{tabular}

Source: authors' own elaboration

The authors then adopt ANOVA test to conduct a Mean Difference Analysis, which is well-recognized to compare whether or not the means of the sampled groups have statistical significance (Freeman, 2005).

The table 7 is the result of the ANOVA test analysed by using SPSS I7.O, which indicates that in 2009, the four profitability indicators do not show significant relationship between the two sampled groups (independent hotels and chain hotels). In other words, the independent hotels have not taken the lead in 2009 according to the four profitability indicators.

Table 7. Mean difference analysis of the profitable performance between the two sampled hotels (2009)

\begin{tabular}{|c|c|c|c|c|c|c|}
\hline \multicolumn{7}{|c|}{ ANOVA } \\
\hline & & Sum of Squares & $d f$ & Mean Square & $\mathrm{F}$ & Sig. \\
\hline \multirow{3}{*}{ EBITDA } & Between Groups & 208.006 & 1 & 208.006 & .451 & .504 \\
\hline & Within Groups & 30919.845 & 67 & 461.490 & & \\
\hline & Total & 31127.851 & 68 & & & \\
\hline \multirow{3}{*}{ GPM } & Between Groups & 12.322 & 1 & 12.322 & .023 & .880 \\
\hline & Within Groups & 36160.075 & 67 & 539.703 & & \\
\hline & Total & 36172.397 & 68 & & & \\
\hline \multirow{3}{*}{ NPM } & Between Groups & 405.151 & 1 & 405.151 & .510 & .478 \\
\hline & Within Groups & 53208.417 & 67 & 794.155 & & \\
\hline & Total & 53613.568 & 68 & & & \\
\hline \multirow{3}{*}{ OPM } & Between Groups & 429.460 & 1 & 429.460 & .576 & .451 \\
\hline & Within Groups & 49977.010 & 67 & 745.926 & & \\
\hline & Total & 50406.469 & 68 & & & \\
\hline
\end{tabular}

Source: authors' own elaboration

\section{Conclusion}

The decision to be an independent or chain affiliated hotel is one of the most critical decisions in a hotel investment. The present study has proved that the independent hotels in Greece gradually perform better than the chain hotels during the period 2008-2OII, but have not taken a dominant position at least in the year 2009.

All the Efficiency and Profitability Indexes of the independent hotels for the period 20082OII are much improved in relation to the respective indexes of the chain hotels based on an average mean analysis. The EBITDA Margin in particular of the individual hotels is much higher in $2 \mathrm{OII}$ (25.40\%), a year during which the Greek upper class hotels increased sales 
and market size (in value). To conduct a financial analysis on economic performances, not only the average mean but ratio analysis and mean differences should be considered as well.

Irrespective of a hotel's development process, both chain and unaffiliated (independent) hotels should focus on sustainable earnings and value. Towards this goal effective asset management is expected to be applied in the complete cycle of a property's development and operation.

The Greek as well as all the hotel enterprises in the world perpetually struggle for profitability and viability.

The identified good practices through this study that follow below can be applied by the Greek hoteliers towards revenues enhancement and viability of their property. At the same time, these practical suggestions also have implications for hotel investors in other countries:

I. Before developing any property, prospective owners should conduct a market and financial feasibility study. Among other information, the feasibility study will provide the project promoters with answers such as whether the investment is profitable and viable.

2. A number of local and global factors (e.g. international tourist arrivals, economic growth, the stock market, etc.) have broad profitability consequences for hotel operators who manage an international portfolio of hotels. One strategy that hotel investors might use for minimizing risk would be to purchase assets in different cities and regions, on the theory that these investments would not be correlated and a drop in one market should be offset by a boom in another (Liu, Moulton \& Quan, 2OI3).

3. Mixed-use developments incorporating retail, entertainment, bars and restaurants, residential and hotel accommodation are increasing in number and scale (Ransley, 2004). It has been found that the mixed-use enterprises operating in Greece had a much higher volume of turnover (sales) in the last 4 years (2OO8-2OII) in comparison to the averages of the total Greek hotel industry (Kapiki, 2OI2).

4. Some very successful and well-known hotel chains report that in order to remain financially viable and operationally sustainable, their properties balance the needs and expectations of various stakeholders (owners, investors and shareholders, colleagues, guests, business partners, suppliers, local community representatives and all others they work closely with) while aiming to contribute to the sustainability challenges facing our world (Shangri-La Asia Limited, 2OIO Sustainability Report \& Sarmaniotis, et al., 2OI3).

5. Environmental certification (e.g. the Green Key, the EU Eco-label, the ISO I4OOI, etc.) contributes significantly in the enhancement of revenues and viability of the hospitality industry. Various surveys show that the majority of the profitable hotels are environmentally certified and apply successful sustainability initiatives. These hotels are committed to economic viability, and social and environmental responsibility (Kapiki, 2OI2).

6. Due to the economic crisis, the hotel companies can replace the loss of the internal market by attracting more foreign tourists. In order to achieve this, they have to develop or adjust their product to the demands of new guests. Therefore, continuous investments (e.g. in renovations and/or new facilities) are needed and also sufficient working capital to support the penetration in new markets.

7. At the operational level, carefully planned and effectively implemented strategies contribute in the success, profitability and viability of the enterprise. The strategies that have been identified as successful towards the sector's profitability (in order of signif- 
icance) are: corporate expansion and continuous investments; guest-centred philosophy; teamwork, highly motivated, productive and competitive staff; exceptional and personalised services; contemporary technological systems; effective marketing techniques; and, several strategic alliances.

\section{Limitations and Future Research}

A limitation to this study is the fact that it concerns only the Greek hotel sector. Another limitation was the reluctance of some hotel managers to share the financial data of their property. In spite of this, the sample is enough for reliable findings and conclusions since the sample's size (bed capacity equal to 76.777 that accounts for the I0.85\% of Greece's total $2^{*}-5^{*}$ capacity) is considered representative.

Future research is suggested to include both international and local companies for more objective conclusions. It should also include and analyse more variables, such as the hotel effectiveness and more specifically the indexes Average annual occupancy, Turnover, Revenue per available room (RevPar) and GOPPAR (gross operating profit per available room) for a long period (e.g. a decade) and benchmark them with the industry averages. The analysis and comparison should be made by the hotel class and location and among several countries.

This is likely to provide a more precise perspective on why and to what extent companies should invest in affiliated or non-affiliated hotels.

\section{References}

Angelo, M. R., Vladimir N. A. (2007). Hospitality Today - An Introduction, $6^{\text {th }}$ Edition, Educational Institute, American Hotel \& Lodging Association, USA.

Association of Greek Tourism Enterprises (SETE). Greek Tourism: Facts \& Figures (2OIO- 2OI2) \& Hotel Capacity per class and Prefecture (2OIO).

Freedman, D. A. (2005). Statistical Models: Theory and Practice, Cambridge University Press. Hellenic Chamber of Hotels. Hotel Capacity 2009 - $20 \mathrm{I} 2$.

Houdre, H. (2008). Sustainable Hospitality: Sustainable Development in the Hotel Industry, Cornell Industry Perspectives, No. 2.

ICAP, Sector Studies, Hotels: Publications 2007-2009, $201 \mathrm{I}, 2 \mathrm{OI} 2$.

Investing in Tourism in Greece (http://www.msolutions.gr/projects/tourism/).

ITEP \& Hellenic Chamber of Hotels (2OI3). Performance of Greek Tourism and developments in the basic figures of the Greek Hotel Market 2OII - $20 \mathrm{O} 2$.

ITEP (Research Institute for Tourism). Developments in the key figures of the Greek hotel market in the years $20 I O-2 O I I$.

Kapiki, S. (2OI2). Implementing Sustainable Practices in Greek Eco-friendly Hotels, Journal of Environmental Protection and Ecology, I3, 2A, III7-II23.

Kapiki, S. (2OI2). Profit Optimization Strategies in Integrated Resorts - Case Study of the Sani Resort, Chalkidiki. International Conference 'Competition and Innovation in Tourism: New Challenges in an Uncertain Environment', 193-205.

Kasavana, L. M., Brooks, M. R. (2005). Managing Front Office Operations. Educational Institute of the American Hotel \& Lodging Association, USA

Koutoulas, D. (2009). The 2009 Greek Hotel Branding Report, (http://www.sete.gr/files/ Media/GreekHotelBrandingReport2009.pdf) 
Liu, C. H., Moulton, P. C., Quan D. C. (2OI3). Common Global and Local Drivers of RevPAR in Asian Cities, Cornell Hospitality Report, I3, I2.

Ozdogan, O. N., Hancer, M., Oter, Z. (2OI3). A Debate on Food Cost \& Sustainability: the Role of Executive Chefs in All Inclusive Hotels. The $\mathrm{II}^{\text {th }}$ Asia Pacific CHRIE conference "Facing the Challenges, Grasping the Opportunities-Winning in the hospitality industry in uncertain times", Macau SAR, China.

Rahman, I., Reynolds, D., Svaren, S. (2OI2). How "green" are North American hotels? An exploration of low-cost adoption practices, International Journal of Hospitality Management, 3I, $72 \mathrm{O}-727$.

Raleigh, L. E. (1999). Evaluating Hotel Franchise \& Chain Affiliation Programs, International Society of Hospitality Consultants, 05/I999 (http://www.ishc.com/).

Ransley, J. (2OO4). Developing Hospitality Properties \& Facilities, $2^{\text {nd }}$ Edition, J. Ransley \& H. Ingram (Eds), Chapter I4: Product development and brand management, Elsevier Butterworth Heinemann.

Sarmaniotis, C., Assimakopoulos, C., Papaioannou, E. (2OI3). Successful implementation of CRM in luxury hotels: Determinants and measurements, EuroMed Journal of Business, 8(2), I34-I53.

Shangri-La Asia Limited (2OIO). Sustainability Report (http://www.hotelschool.cornell.edu/ research/chr/events/roundtables/sustainability/documents/Shangri-LaAsia2OIOSustainabilityReport.pdf).

Slattery, P. (2004). Developing Hospitality Properties \& Facilities, $2^{\text {nd }}$ Edition, J. Ransley \& H. Ingram (Eds), Chapter 4: Development strategy, Elsevier Butterworth Heinemann.

UNEP-United Nations Environment Program (2005). Making Tourism More Sustainable: a Guide for Policy Makers (http://www.unep.fr/shared/publications/pdf/DTIxO592xPA-TourismPolicyEN.pdf). 